\title{
Ayasofya ve Topkapı Sarayı Müzesi Bilişsel ve Duygusal Müze İmajı Algısı: Yabancı Turistler Üzerine Bir Araştırma

\author{
(Araştırma Makalesi)
}

Cognitive and Emotional Museum Image Perception towards Hagia Sophia and Topkap Palace Museum: A Research on Foreign Tourists

Doi: 10.29023/alanyaakademik.707190

Seçkin ESER

Dr. Ögrr. Üyesi, Kırklareli Üniversitesi Turizm Fakültesi

seckineser@klu.edu.tr

Orcid No: 0000-0001-9972-5818

\section{Zafer ERLER}

zafererler39@gmail.com

Bu makaleye atıfta bulunmak için: Eser, S., \& Erler, Z. (2020). Ayasofya ve Topkapı Sarayı Müzesi Bilişsel ve Duygusal Müze İmajı Algısı: Yabancı Turistler Üzerine Bir Araştırma. Alanya Akademik Bakış, 4(3), Sayfa No. 1083-1099.

\section{Anahtar kelimeler: \\ Bilişsel Müze İmajl, Duygusal Müze Imajl, \\ Müze Imajı, Ayasofya Müzesi, Topkapı Sarayı Müzesi}

Makale Geliş Tarihi: 21.03.2020

Kabul Tarihi:

29.09.2020

Keywords:

Cognitive Museum

Image,

Emotional Museum

Image,

Museum image,

Hagia Sophia

Museum,

Topkapi Palace

Museum

\begin{abstract}
ÖZET
$\overline{\text { Müzeler, turizm açısından önemli unsurlardır. Müzelerin turizm alanında }}$ başarı kazanması için müze imajı önemli bir etkendir. Bu çalışmanın amacı yabancl turistlerce algılanan bilişsel ve duygusal müze imaj algisinin belirlenerek, Ayasofya ve Topkapı Sarayı Müzesi açısından karşılaştırmasının yapılmasıdır. Veriler, gelişstirilen anket ile iki müzeyi ziyaret eden 527 yabancı turiste, 8 Aralık 2018 - 8 Şubat 2019 tarihleri arasında yüz yüze uygulanmasıyla elde edilmiştir. Araştırmanın, sonuçlarına göre; müzeler arasinda bilişsel ve duygusal imaj açısından anlamlı bir fark olduğu sonucuna varılmış ve yabancı turistlerin her iki müzeye yönelik bilişsel ve duygusal imaj algisının olumlu yönde olduğu tespit edilmiştir. Ancak iki müzenin de bilişsel ve duygusal açıdan dünyadaki ziyaretçi sayısı yüksek müzelerle rekabet edebilmesi için hala çalışmalara ihtiyaç duyulduğu ve eksik yönlerinin bulunduğu söylenebilir.
\end{abstract}

\begin{abstract}
Museums are important elements for tourism industry. The museum image is significant in the success of museums in the field of tourism. The aim of this study is to determine the cognitive and emotional museum image perception perceived by foreign tourists and make a comparison between Hagia Sophia and Topkapi Palace Museum. Using a structured questionnaire, the data was obtained face to face between 8 December 2018 - 8 February 2019 from 527 foreign tourists visiting the museums. According to the results of the research; it was concluded that there was a significant difference between the museums in terms of cognitive and emotional image and it was determined that foreign tourists have positive image perceptions towards
\end{abstract}


these two museums However, it can be said that these museums have deficiencies and need more efforts in terms of cognitive and emotional aspects in order to compete with museums those which have higher number of visitors.

\section{GİRİş}

Müzeler, bir toplumun sahip olduğu kültürel, tarihsel ve ortak değerleri yansıtır. Müzeler insanların merakı ve boş zamanı değerlendirme arzusu ile artan aktiviteleri nedeniyle turizm açısından önemli hale gelmiştir (Boyar, 2006: 28-29). Ulusal ve uluslararası kültürel mirasın sergilendiği, bakımının yapıldığı, saklandığı, korunduğu, ve geleceğe aktarıldığı, müzeler eğitici ve toplumu eğlendirici imkanlar sunan kurumlardır (Mercin, 2003: 112). Turizm sayesinde bu kurumlarda saklanan eserlerin ve koleksiyonların bilinirliği artmış ve müzeler turizm açısından önemli birer çekim merkezleri haline gelmiştir (Kervankıran, 2014: 348).

Her işletme gibi müzelerin de temel hedefleri bulunmaktadır. Müzelerin genel hedefleri; ait olduğu toplumla ilişkisini güçlendirmesi, ziyaretçi kitlesini ve sayısını artırması, ziyaretçi kitlesine bağlı olarak imajını geliştirmesi ve müze ziyaretçilerinin ilgi alanlarını, ihtiyaçlarını en iyi şekilde karşılamasıdır (Kotler ve Kotler, 2000: 275).

İmaj, tüm zihinsel görüntüleri ve bu görüntülerle ilgili süreçleri, özellikleri, kapsamı ve toplam bilişsel yapıyı ifade etmek için kullanılır (Altınbaşak ve Yalçın, 2009: 242). Bu kavram, küreselleşen dünyada artan rekabetle birlikte işletmeler açısından önem kazanmıştır. Hedef kitlelerin üzerinde yarattığı olumlu imaj, pazarlama faaliyetlerini kolaylaştırmakta ve müşteri memnuniyetinin artmasında önemli bir etki yaratmaktadır (Gürkan, 2008: 34).

Bir müzenin imajı ise, bireylerin müzenin sahip olduğu yerler, sergiler, salonlar hakkında izlenimleri veya algıları olarak tanımlanabilir. Bireyler genel olarak müzelerle ilgili nitelikler hakkında bilgi sahibidirler. Bu sebeple, müze imajı bireyin müze kütlesinin elenmesi yoluyla oluşturulmuş bir zihinsel resme denir (Vaughan, 2001: 253-254). Müze imajı kavram1 3 ana boyuttan (bilişsel, duygusal ve genel) oluşmuştur. Bilişsel müze imajı, müzenin sahip olduğu fiziksel özellikler, içerisinde yapılan etkinlikler, çalışanlar ve bölümler hakkındaki kişilerin değerlendirmesidir (Çerçi, 2013: 50-54). Duygusal müze imajı turistlerin müze hakkında sahip oldukları duygusal anlam yükledikleri imaj türüdür (Akbulut, 2014: 32-33). Genel müze imaj1 ise bireylerin bir bölgeyi veya yeri ziyaret etmeden önce sahip oldukları bir hedefin genel görüntüsüne denir (Gil ve Ritchie, 2017: 535). Dolayısıyla, duygusal ve bilişsel imajın bir sonucu olarak tutulan genel duygulara dayanmaktadır (Vaughan, 2001: 256). Genel müze imajı, hem duygusal hem bilişsel müze imajının birleşimini, yarattığı genel algıyı ifade etmektedir.

Müzelerin başarılı olması ve hedeflere ulaşılması için müzeyi diğer müzelerden ve eğlence unsurlarından farklı kılan çeşitli özelliklere sahip olması ve ziyaretçilerin istek ve ihtiyaçlarını karşılayabilmesi gerekmektedir (Vaughan, 2001: 253-254). Bu bakımdan müze imajı kavramı önem kazanmaktadır. Müze imaj kavramını oluşturan iki temel boyut ta (bilişsel ve duygusal imaj boyutu) bu açıdan önemlidir. Belirtilen bu iki boyut aynı zamanda ziyaretçilerin genel müze imaj algısının oluşmasında etkilidir. Vaughan (2001) çalışmasında ziyaretçilerin bilişsel imaj algılarının müzenin yapısı, personeli ve göstergeleri olduğunu ifade etmiştir. Gil ve Ritchie (2009), duygusal imajın, bir yerin uyandırdığg duyguları ifade ettiğini belirtmiştir. 
Bu noktada çalışmanın temel amacı; yabancı turistlerin müzelere dönük bilişsel ve duygusal imajının ortaya konulması ve Topkapı Sarayı ve Ayasofya Müzesi'nin sahip olduğu bilişsel ve duygusal öğelerin karşılaştırılmasıdır. Türkiye'de tarih, kültür, nüfus ve turist sayısı bakımından zengin, en çok bilinen ve öne çıkan şehirlerden biri İstanbul şehridir. Çalışma kapsamında seçilen, İstanbul şehrinin en çok ziyaretçi alan iki müzesi ise Topkapı Saray1 Müzesi ve Ayasofya Müzesi'dir (İstanbul İl Kültür ve Turizm Müdürlüğü, 2019). Bu sebeple iki müze tercih edilmiştir. Çalışmada öncelikle müze ve müzecilik kavramlarına, önemine, müzelerin hedeflerine, imaj ve müze imajı kavramına, bilişsel ve duygusal imaj boyutları ve öğelerine değinilmiştir. Çalışma; yabancı turistlerin Ayasofya ve Topkapı Sarayı Müzesi'ne yönelik bilişsel ve duygusal müze imajı algısının incelenmesi açısından alan yazınına katkı sağlamaktadır.

\section{MÜZE VE MÜZECILIIK KAVRAMLARI}

Milletlerarası Müzeler Konseyi (ICOM) Türkiye Milli Komitesinin tanımına göre; kültür yapıtlarını koruyan ve bu yapıtları etüd, eğitim ve daha zevkli hale getirmek için toplu halde teşhir eden kamu yararına çalışan, sanata, ilme, sağlığa, teknolojiye ait koleksiyonlara sahip kurumlara müze denir (ICOM, 2018). Müzecilik ise; Kültür ve Tabiat Varlıklarını Koruma Kanunu kapsamına giren korunması gereken taşınabilir kültür ve doğa varlıklarının ve envanter işlemlerinin müzelerde ne şekilde uygulanması gerektiği ile ilgili kuralları belirlemektir. Ayrıca uygulamada birlik oluşturmak ve müzelerde ve ören yerlerinde bulunan taşınabilir veya taşınamayan eserleri korumak ve gerekli önlemleri almaktır (Kültür ve Turizm Bakanlığ 1,2019$)$.

Günümüzde dünyanın farklı bölgelerinde veya çoğu ülkede faaliyet gösteren müzeler varlığını devam ettirebilmesi için belli hedef ve amaçları bulunmaktadır. Yönetilmek istenen kurum veya kuruluş, proje, müze her ne olursa olsun işletmelerin belli hedefleri, amaçları ve stratejileri olması gerekmektedir. İlk kurulduğu yıllarda müzelerin başlıca görevleri; eserleri ve kıymetli eşyaları toplamak, belgelemek, korumak ve belli bir alanda sergilemekti. İlerleyen yıllarda gelişen teknolojiyle toplumların bilinçlenmesi, estetik kaygının önem kazanması ve ziyaretçilerin istek ve ihtiyaçlarının en iyi şekilde karşılanması gibi değişen değerlerle müzeler bir eğitim kurumu olma özelliği de kazanmıştır (Aksoy, 2016: 9).

Topkapı Sarayı, Osmanlı devletinin eğitim ve yönetim merkezi, padişahların ikametgâh yeridir. Osmanlı devleti padişahı Fatih Sultan Mehmet tarafindan 1460-1478 yılları arasında inşa edilmiş ve ilerleyen zamanlarda ilaveler yapılan saray, 19.yüzyılın ortalarına kadar Padişah ve saray halkı tarafından kullanılmıştır. Topkapı Sarayı, 1922 yılında Osmanlı devleti yıkıldıktan sonra 3 Nisan 1924 tarihinde Mustafa Kemal Atatürk'ün emriyle müze olmuştur (Topkapı Sarayı Müzesi, 2019). Topkapı Sarayı Müzesi Osmanlı devletinin yönetim merkezi, padişahların yaşam yeri olan, Osmanlı dönemine ait önemli birçok değerli İslam eseri barındırmasından dolayı Türk ve İslam tarihi ile dünya tarihi açısından önemli bir müze imajına sahiptir.

Dünya çapında mimarlık tarihinin çağımıza kadar gelen mühim eserleri arasında bulunan Ayasofya, mimari, büyüklük, ihtişam, işlevsellik ve sanatsal açıdan da önem arz etmektedir. Ayasofya Doğu Roma İmparatorluğu'nun İstanbul'da inşa ettiği en büyük kilisedir. 916 yıl kilise olarak kullanılan Ayasofya, Fatih Sultan Mehmet'in 1453 tarihinde İstanbul'u fethetmesiyle birlikte cami olarak 482 yıl hizmet vermiştir. Ayasofya 1 Şubat 1935 tarihinde Mustafa Kemal Atatürk’ün emri ve Bakanlar Kurulu kararıyla müzeye dönüştürülmüş ve 
turistlerin ziyaretine açılmıştır (Ayasofya Müzesi, 2019). Dünya'da iki ilahi dine ve 2 büyük kültüre (Bizans ve Osmanlı Devleti) ev sahipliği yapmış müze imajı bakımından Türkiye'de önde gelen müzelerden biridir.

Araştırmanın yapıldığı dönem içerisinde; çalışma kapsamında 2017 Kültür ve Turizm Bakanlığı müze ziyaretçi sayıları alınmıştır. Kültür ve Turizm Bakanlığg 2018 yılı verilerine göre, İstanbul Topkapı Sarayı Müzesi’ni 3.004.620 kişi, İstanbul Ayasofya Müzesi'ni ise 2.922.037 kişi ziyaret etmiştir. Bu müzeler Türkiye'de en fazla ziyaretçi sayısına sahip olan ilk iki müzedir.

\section{3. İMAJ KAVRAMI, MÜZE IMAJI ve ALANYAZIN İNCELENMESI}

İmaj, Latince ‘imago’ kökünden gelmekte olup, insanın zihninde bir birey, ürün, kuruluş, olay vb. durumlar için geliştirdiği psikolojik ve bilişsel bir görüntüyü tanımlamaktadır. Literatürde farklı tanımlar mevcut olsa da imaj kavramı sözcük olarak duyu organlarının dıştan algıladığı bir objenin bilince yansıyan benzer halidir (TDK, 2019). Globalleşmenin etkisiyle yaşanan ekonomik değişimler işletmelerin rakiplerinden daha güçlü ve farklı bir imaja sahip olmasını gerekli kılmaktadır (Hatch ve Schults, 1997: 14).

İmajın tanımlarından yararlanılarak, Baloğlu ve McCleary (1999), Vaughan (2001) ve Beerli ve Martin (2004)'e göre imaj kavramının üç ana boyutu bulunmaktadır. Dolayısıyla, müze imajı kavramı 3 ana boyuttan (bilişsel, duygusal ve genel) oluşmaktadır.

Bilişsel imaj karmaşık bir yapıya sahiptir, birbiriyle ilişkili bir dizi fiziksel ve psikolojik imgelerden ve yorumlardan oluşmaktadır (Gil ve Ritchie, 2009: 482). Müze açısından bilişsel imaj algılarını müzelerin yapısı, personeli ve müzelerin içerisinde bulunan imgeler oluşturmaktadır. (Vaughan, 2001: 255). Müzelerin sahip olduğu bilişsel imaj öğeleri; park yeri, hediyelik eşya dükkanı, müzenin içindeki görsel animasyon, müzede kullanılan teknoloji ve müzenin dışındaki işaret veya içindeki işaretler, mimarisi, ücreti, konumu, ziyaret süresi, nesneler, girişi, bakımı, yapılan indirimler ve dekorasyonu gibi konulardır. Duygusal imaj, bir bölge, yer ve kurumla ilgili kişilerin hisleri olarak tanımlanmaktadır (Yazıcıŏlu ve Akbulut, 2015: 138). Duygusal imaj; müzenin içinde bulunduğu ortamın sıkıcı veya canlandırıcı, sıradan veya şaşırtıcı, hoş veya hoş olmayan, uyarıcı veya teşvik edici, boğucu veya heyecan verici, pasif veya aktif gibi duygusal özellikleri kapsamaktadır (Gil ve Ritchie, 2017: 540). Bahsedilen tanımlar çerçevesinde, genel müze imajı bir bireyin bir müze ile ilgili işleyiş, eserler, sergiler, etkinlikler, kullanılan teknolojiler gibi farklı tüm özellikleriyle ilgili genel yargısı olarak ifade edilmektedir (Gil ve Ritchie, 2009: 480-483).

Literatürde müze imajı ile ilgili olarak ilk yapılan çalışma Rosenberg, Hovland, McGuire, Abelson, ve Brehm (1960) tarafından gerçekleştirilen yerel halk müzelerinin sahip oldukları olumlu imaja odaklanan çalışmadır. Harrison (1997) tarafından yapılan başka bir çalışma da turistlerin yerel bir müzeyi ziyaret etmeden önce, o müzeye yönelik algılanan imajı incelemiştir. Vaughan (2001) müze imajı ile ilgili yaptığı çalışmada; müzede bulunan imgelerin yerel halkın müzeleri ziyaret etme deneyimleri üzerinde etkili olduğunu belirtmiştir. Ayrıca bu çalışma, imaj etki faktörlerinin yerel halk ve turistler açılarından farklılaştığını ortaya koymaktadır. Gil ve Ritchie (2009) çalışmalarında müze imajı kavramını ve boyutlarını açıklamıştır. Gil ve Ritchie (2017) bir turizm destinasyonunda algılanan müze imajı ve boyutlarını değerlendirmiştir. 
Yerli alan yazında, müze imajı ve imaj boyutları ile ilgili herhangi bir araştırmaya rastlanmamıştır. Türkiye'de "müze ve ziyaretçiler" ile ilgili yapılan çalışmalar şu şekilde özetlenebilir: Demir (1998), müzelerde pazarlama, çağdaş pazarlama ve müze-ziyaretçi ilişkisi üzerinde durmuştur. Çalışmada; Ayasofya Müzesi ve İstanbul Arkeoloji Müzesi’nin yerli turistler açısından çeşitli özellikleri (park yeri, yön gösterme, koleksiyon, müze bakımı), ziyaretçi profilleri ve görüşleri karşılaştırılmıştır. Özgören (2007) boş zaman pazarlaması ve müzecilikle ilgili yapmış olduğu çalışmada, Topkapı Sarayı Müzesi'ni müze özellikleri (müze binası, çalışma saatleri, koleksiyonlar, yön gösterme tabelaları, giriş ve çıkış bölümleri, bakım), müze ziyaret sıklığı, müze ziyaret sebepleri, beğenilme durumu ve boş zaman pazarlaması açısından değerlendirmiştir. Kırca (2008), ise çalışmasında turistlerin müzelere olan ziyaret alışkanlıkları ve tercihlerini belirlemiştir.

Topkapı Sarayı ile Ayasofya Müzesi bilişsel imaj boyutu açısından değerlendirildiğinde; ziyaret süresi, konum ve diş yönlendirme tabelaları, ücret, indirimler açısından benzerlik göstermektedir. Ancak iki müze içerisinde yer alan koleksiyonların çeşitleri ve sayısı bakımından farklılıklar bulunmaktadır. Ayasofya Müzesi kilise eşyaları, türbe eşyaları, taş eserler gibi koleksiyonlar içerirken, Topkapı Sarayı Müzesi'nde padişah elbiseleri, silahlar, kutsal emanetler, mutfak eşyaları, Avrupa porselenleri ve camları, gümüşler, Çin ve Japon porselenleri, imparatorluk hazinesi gibi çok sayıda koleksiyon sergilenmektedir.

Topkap1 Sarayı ve Ayasofya Müzesi'nin mimarisi, restorasyonu, dekorasyonu, iç yönlendirme tabelası sayısı ve niteliği, hediyelik eşya dükkânlarının özelliği ve çeşitleri, giriş bölümleri bakımından farklılık gösterdiği söylenebilir. Topkapı Sarayı Müzesi önceleri saray olarak kullanıldığından mimari açıdan 4 avlu ve haremden oluşmakta, Ayasofya Müzesi ise ibadethane olma özelliğinden dolayı biri iç ve diğeri dış mekan olmak üzere 2 bölümden oluşmaktadır (Ayasofya Müzesi ve Topkapı Sarayı Müzesi, 2019).

Demir (1998) çalışmasında yerli turistlerin Ayasofya Müzesi'nin çalışma saatlerinin, yön gösterici unsurların, koleksiyon ve müze bakımının yeterli seviyede olduğunu belirttiklerini ve olumlu bir bakış açısına sahip olduklarını ifade etmiştir. Özgören (2007) çalışmasında yerli turistlerin Topkapı Sarayı Müzesi'nin müze girişini, koleksiyonu ve bakımını iyi bulmalarına rağmen, müze çalışma saatlerini, yön gösterici tabelaları ve hediyelik eşya dükkanını ortalama düzeyde değerlendirmişlerdir. $\mathrm{Bu}$ açıklamalar doğrultusunda; Topkapı Sarayı ve Ayasofya Müzesi'nin benzer özellikleri bulunmakla birlikte yabancı turistlerce bilişsel imaj açısından farklılık gösterebileceği sonucuna ulaşılmıştır. $\mathrm{Bu}$ kapsamda iki hipotez belirlenmiştir;

H1: Ayasofya ve Topkapı Sarayı Müzesi’nin yabancı turistlerce algılanan bilişsel müze imajları birbirinden farklıdır.

Topkapı Sarayı ve Ayasofya Müzesi duygusal imaj boyutu açısından fiziksel ve mistik olarak değerlendirildiğinde; iki müzenin farklı amaçlarla inşa edilmiş ve kullanılmış olması nedeniyle yabancı turistler açısından farklı bir atmosfer yaratmaktadır. Ayasofya iki semavi din açısından da önemli bir merkezdir. Ayasofya Müzesi'nin farklı dinlere ve kültürlere ev sahipliği yapması ve yüzyıllarca ibadethane olarak kullanılması Hristiyanlar ve Müslümanlar açısından duygusal imaj bakımından farklı değerlendirilebilmektedir. Topkapı Sarayı Müzesi'nin de yaklaşık 400 yıl boyunca Osmanlı devletinin yönetim merkezi olması nedeniyle Türk ve Müslümanlara ait önemli eserlerle Ayasofya Müzesi'nden farklı bir atmosfere sahiptir. 
Ayasofya Müzesi'nin ibadethane özelliği, Topkapı Sarayı Müzesi’nin de Saray olma özelliğinden dolayı iki müze duygusal olarak farklı algılanabilir. Ayasofya Müzesi içerisinde kilise eşyaları, dinlere ait süslemeler, duvar resimleri gibi ibadethane olma özelliğinden kaynaklı koleksiyonlar bulunmaktadır. Topkapı Sarayı Müzesi de saray olma özelliğinden dolayı Türk-Osmanlı kültür ve inanç unsurlarına ait farklı koleksiyon ve bölümlerden oluşmaktadır. Topkapı Sarayı Müzesi Osmanlı Devleti padişahlarına ait elbiseler ve resimler bölümü, imparatorluk hazinesi bölümü, divan bölümü, kutsal emanetler gibi koleksiyonlar ve farklı kısımlardan oluşmaktadır. İki müze farklı amaçlarla inşa edilmiş ve kullanılmış olmasından ve içinde bulundurduğu eser ve koleksiyonların farklılığından dolayı yabancı turistlerde farklı duygular uyandırabilir (Ayasofya Müzesi, 2019 ve Topkapı Sarayı Müzesi, 2019).

Kırca (2008) çalışmasında yerli turistler tarafından en beğenilen müzenin Ayasofya Müzesi olduğunu, Topkapı Sarayı Müzesi'nin ise ikinci en beğenilen müze olduğunu belirtmiştir. Bu durumda iki müzenin de duygusal açıdan olumlu imajlara sahip olduğu ancak birbirinden farklı bir duygusal imaj yaratacağı söylenebilir. Bu açıklamalar doğrultusunda; Topkap1 Sarayı ve Ayasofya Müzesi'nin duygusal imaj açısından yabancı turistlerce farklılık gösterebileceği sonucuna ulaşılmıştır. Bu kapsamda aşağıdaki hipotez belirlenmiştir.

H2: Ayasofya ve Topkapı Sarayı Müzesi'nin yabancı turistlerce algılanan duygusal müze imajları birbirinden farklıdır.

\section{ARAŞTIRMANIN AMACI}

Müze ziyaretleri olumlu bir ülke imajının oluşmasında, ülkenin ve müzelerin bulunduğu destinasyonların tanınmasının sağlanmasında, hem sosyo-kültürel hem de ekonomik açıdan katkı sağlayabilecek unsurlardır. Bu nedenle çalışmada, turizm sektörünün önemli bir bileşeni olan müzeler ve müze ziyaretleri ele alınarak; yabancı turistlerin bilişsel ve duygusal müze imajının algılarının belirlenmesi amaçlanmıştır.

Müze imajının temel bileşenleri olan bilişsel ve duygusal müze imajı; müzelerin başarısında, tanınırlı̆̆ında ve turistlerin ziyaret tercihleri gibi hususlarda farklılığa neden olabileceği gibi, müzelerin eksiklerinin belirlenmesinde ve gelişiminde de yarar sağlayabilmektedir. $\mathrm{Bu}$ sebeple bu çalışmanın amacı, müzeleri ziyaret eden yabancı turistlerce algılanan bilişsel ve duygusal müze imajı boyutunun belirlenmesidir. İki müzenin bilişsel ve duygusal imaj boyutu açısından karşılaştırması yapılacaktır. Yabancı turistlerce algılanan bilişsel ve duygusal müze imajının belirlenmesi, müzelere yönelik beğeni ve eleştirilerin ortaya konması ve değerlendirilmesi, müzelerin geliştirilmesinde, yetkililerin doğru pazarlama kararları alabilmelerinde katkı sağlayabilir.

\section{ARAŞTIRMANIN YÖNTEMI}

Araştırmada veriler, geliştirilen bir anket ile toplanmıştır. Anketin hazırlanmasında konu ile ilgili ulusal ve uluslararası yazın taranmıştır. Bilişsel imaj ölçeğinde 16 ve duygusal imaj ölçeğinde ise 7 madde bulunmaktadır. Konu ile ilgili ölçekler Gil ve Ritchie"nin (2009) çalışmasından alınmış olup; tepki kategorileri “1:Çok kötü, ..., 7: Çok iyi”" şeklinde 7’li Likert derecelemesine tabi tutulmuştur.

Araştırmanın evrenini Türkiye'de müzeleri ziyaret eden yabancı turistler oluşturmaktadır. Çalışma evreni ise Türkiye'de 8 Aralık 2018-8 Şubat 2019 tarihleri arasında İstanbul Topkapı Sarayı ve Ayasofya Müzesi'ni ziyarete gelen yabancı turistlerden oluşmaktadır. Örneklemin 1088 
hesaplanmasında Kültür ve Turizm Bakanlığı web sitesinin 2017 yılı istatistiklerinde belirtilen iki müzeyi ziyaret eden yabancı turist sayısı kullanılmıştır. Bu bağlamda, 2017 yılı verilerine göre; Ayasofya Müzesi'ni 1.892.250, Topkapı Sarayı Müzesi'ni 1.932 .726 kişi ziyaretçi etmiştir. Bu rakamların toplamına göre araştırma evrenini oluşturan ziyaretçi sayısı 3.824.976 kişidir. Müzeleri gezen turist sayısının 10.000 'den fazla olması nedeniyle sınırsız evrenlerde ortalama için kullanılan örnek büyüklüğü hesaplama formülünden yararlanılmıştır (Ural ve Kılıç, 2013: 47). Rakamlar temel alınarak yapılan ayrımda; ziyaretçilerin \%50.53'ü Topkapı Sarayı Müzesi’ni ve \%49.47'si Ayasofya Müzesi’ni ziyaret etmiştir. Bu sebeple 2 müzede eşit oranda örneklem alınması tercih edilmiştir.

Topkapı Sarayı ve Ayasofya Müze imajı ile ilgili rapor edilen bir standart sapma değeri bulunmamaktadır. Örnek büyüklüğünün hesaplanabilmesi için, rapor edilmiş bir standart sapmanın olmaması nedeniyle, standart sapmanın tahmin edilmesi yoluna gidilmiştir. Değişim aralığının ( $\mathrm{R}=$ Max.-Min) 6'ya bölünmesi durumunda Alfa $=0.01$ için tahmini standart sapma elde edilmiş olur (Yolal, 2016: 68). 7'li derecelemede değişim aralığ, $\mathrm{R}=7$ 1=6'dür. Bu aralığın 6'ya bölünmesi ile tahmini standart sapma 1,00 olarak hesaplanmıştır. Örnekten elde edilecek ortalamanın \%5 anlam düzeyinde evren ortalamasından H: 0.10 dolayında sapma göstermesine karar verilerek, ulaşılması gereken örnek büyüklüğü 384 kişi olarak tespit edilmiştir (Ural ve Kılıç, 2013: 45). Rakam 400'e çıkarılarak anketin yarısının Ayasofya Müzesi'nde, diğer yarısının da Topkapı Sarayı Müzesi'nde uygulanmasına karar verilmiştir.

$$
\mathrm{n}=\sigma 2 * \mathrm{Z} 2 \alpha / \mathrm{H} 2=1,962 * 12 / 0.102=3.84 * 1 / 0.01=384^{1}
$$

Oluşturulan anket, 2019 yılı Aralık ayında 70 yabancı turiste uygulanarak ön test yapılmıştır. Ön test neticesinde, anlaşılmayan, açık olmayan soruya rastlanmamıştır. Anket, Topkapı Sarayı ve Ayasofya Müzesi'ni ziyaret eden yabancı turistlere, 8 Aralık 2018 - 8 Şubat 2019 tarihleri arasında uygulanmıştır. Anketler, müze ziyaretçilerine yüz-yüze uygulanmıştır. Anketler müze içinde, müze çıkış kapılarında ve müze çevresinde müzeyi ziyaret etmiş ve ankete katılmaya istekli olan yabancı turistlere uygulanmıştır. Tam ve doğru olarak doldurulmuş anket sayısına ulaşmak için bilinçli olarak daha fazla anket dağıtılmıştır. Toplamda 535 anket dağıtılmıştır. Toplanan her anket titiz bir değerlemeye tabi tutulmuş, ölçek maddelerinin tamamının yanıtlandığı görülmüş, 8 anket kullanım dışı bırakılmış ve analiz ve değerlemeler 527 anket üzerinden yapılmıştır. Verilerin analizinde; tanımlayıcı istatistiklerin yanı sıra, t-testinden yararlanılmıştır.

\subsection{Güvenilirlik ve Geçerlilik}

Araştırmada bir müze imajı ölçeği kullanılmıştır. Bu ölçek bilişsel, duygusal ve genel imaj şeklinde 3 boyuta sahiptir. Bilişsel imajın güvenilirlik analizi 0.853 'dür. Duygusal imajın güvenilirlik analizi 0.884 'dür. Bu güvenilirlik değerleri sonuçları her 2 boyutun da yüksek derecede güvenilir olduğunu göstermektedir. Madde bütün korelasyonlarının 0.848 ile 0.460 arasında değiştiği ve tespit edilmiştir. $+0,200$ 'ün altında hiçbir maddenin olmaması nedeniyle ölçekten herhangi bir madde çıkarılmamıştır. Güvenilirliğin yüksek çıkması katılımcıların ölçeklere ilişkin cevaplarının tutarlı olduğunu ve teoriye uygun önermelerden oluştuğunu göstermektedir (Alpar, 2016: 562).

\footnotetext{
${ }^{1} \mathrm{n}=\sigma 2 . Z 2 \alpha / \mathrm{H} 2=1,962 * 12 / 0,102=384$ [n: Örneklem büyüklüğü; Z: Belirli anlamlılık düzeyine karş1lık gelen teorik değer ( $\alpha: 0,05$ için $Z$ değeri 1,96'dır), $\sigma$ : Standart sapma değeri, H: Standart hata değeri]
} 


\section{BULGULAR}

Araştırma kapsamında iki müzenin bilişsel ve duygusal müze imaj boyutları (Topkapı Sarayı ve Ayasofya Müzesi) belirlenmiştir. Araştırmaya katılan yabancı turistlerin \%52.2'si (275 kişi) Ayasofya Müzesi'ni, \%47.8'i (252 kişi) ise Topkapı Sarayı Müzesi’ni ziyaret eden turistlerden oluşmaktadır. Buna göre; araştırmada belirtilen iki müzeyi ziyaret eden turist oranları hemen hemen birbirine yakın olmakla birlikte, çoğunluğunu (\%52.2) Ayasofya Müzesi'ni ziyaret eden yabancı turistler oluşturmaktadır. Araştırmaya katılan turistlerin $\% 54.1$ 'i erkek, \%45.1'i kadındır.

Araştırmaya 44 farklı uyruğa sahip yabancı turist katılmıştır. Araştırma kapsamında, yabancı turistlerin \%12'sinin (63 kişi) Rusya uyruklu olduğu belirlenmiştir. Rusya'yı sırasıyla \%9.5 (50 kişi) ve \%8.5 (45 kişi) ile Endonezya ve Malezya izlemiştir. Dördüncü sırada Amerikan uyruklu 41 kişi (\%7.8) ve beşinci sırada ise Çin uyruklu 39 kişi (\%7.4) yer almaktadır. Diğer başlığı altında yer alan 32 millet katılımcıların \%22'sini (116 kişi) oluşturmaktadır. Ayrıca, katılımcıların uyruklarına göre, ülkelerinin kıtasal ayrımları yapıldığında, büyük bir kısmının (334 kişi) Asya kıtasına ait milletlerden biri olduğunu belirlenmiştir. Kıtalarına göre ayrımda; katılımcıların \%22.2'si Avrupa, \%9.9'u Kuzey Amerika, \%3.6'sı Afrika ve \%0.9'uda Güney Amerika kıtası olarak belirtmişlerdir.

Araştırmaya katılan yabancı turistlerin \%44.4'ü (234 kişi) 25-34 yaş aralığında olup bu grup yaş bakımından ilk sırada yer almaktadır. Araştırmada 18-24 yaş aralığı örneklemin \%28.7'sini, 35-44 yaş aralığ \% \%20.3'ünü ve 45-64 yaş aralığ ise \%6.6'sını temsil etmektedir. Eğitim durumu dikkate alındığında; yabancı turistlerin \%52.2'si lisans mezunu, \%17.6'sı ön lisans mezunu, \%15.7'si lise mezunu, \%14.6'sı da lisansüstü mezunu olduklarını belirtmişlerdir.

Katılımcıların \%38.3'ü Türkiye'yi daha önce ziyaret etmişken, \%61.7'sini oluşturan 305 kişi Türkiye'yi daha önce ziyaret etmediklerini belirtmişlerdir. Türkiye'yi ziyaret etmiş olan 202 kişi 12 farklı destinasyon belirtmişlerdir. Yabancı turistler tarafindan en çok ziyaret edilen şehir \%33.2 oranla Antalya olmuştur. Daha sonra 54 kişi (\%26.7) ile İstanbul ikinci sırada yer almaktadır. Yabancı turistlerin \%15.8'i Nevşehir'i, \%7.9 İzmir'i ziyaret ettiğini belirtmiştir. Ayrıca katılımcıların diğer seçeneği altında belirttiği 8 şehir (Denizli, Muğla, Konya, Çanakkale, Ankara, Bursa, Trabzon, Gaziantep) 33 kişi (\% 16.3) tarafından ziyaret edilmiştir.

Araştırma kapsamında yabancı turistlere daha önce müze ziyaretinde bulunup bulunmadıkları sorulmuştur. Daha önce müze ziyareti yapmış olan 408 kişi (\%77.4) 49 farklı müzeyi ziyaret ettiğini belirtmiştir. Yabancı turistler tarafından en çok ziyaret edilen müze \%10.8 oran ile dünyada en çok ziyaret edilen müzelerin başında gelen Paris Louvre Müzesi'dir. Katılımcıların daha önce ziyaret ettiğini belirttiği ikinci müze \%6.9 oranla Dolmabahçe Sarayı Müzesi'dir. Sırasıyla \%6.6 , \%6.1 ve \%5.9 oran ile katılımcılar; dünyada en çok ziyaretçi alan 10 müze arasında bulunan; New York Metropolitan Sanat Müzesi'ni, Rusya Hermitage Müzesi’ni ve Rusya Puşkin Müzesi’ni belirtmişlerdir. 
Tablo 1.Bilişsel İmaj Unsurlarının Müzelere Göre Karşılaştırılması

\begin{tabular}{|c|c|c|c|c|c|c|}
\hline \multirow[b]{2}{*}{ Bilişsel İmaj } & \multicolumn{2}{|c|}{$\begin{array}{l}\text { Ayasofya; } \\
\text { n:275 }\end{array}$} & \multicolumn{2}{|c|}{$\begin{array}{l}\text { Topkapı; } \\
\text { n:252 }\end{array}$} & \multirow[b]{2}{*}{$\underset{\text { değeri }}{\mathrm{t}-}$} & \multirow[b]{2}{*}{ p değeri } \\
\hline & Ort. & $\begin{array}{c}\text { S.Sap } \\
\text { ma }\end{array}$ & Ort. & $\begin{array}{c}\text { S.Sap } \\
\text { ma }\end{array}$ & & \\
\hline 1. Müze içindeki tabela veya yönler & 5.68 & 1.02 & 5.76 & 1.00 & -1.38 & 0.167 \\
\hline $\begin{array}{l}\text { 2. Yorumsal Materyaller (Müze } \\
\text { içerisindeki yoruma açı canlandırma } \\
\text { için kullanılan materyaller) }\end{array}$ & 5.19 & 1.18 & 5.43 & 1.05 & -3.29 & $\mathrm{p}<0.001$ \\
\hline $\begin{array}{l}\text { 3. Farkl1 salonlar / sergiler arasındaki } \\
\text { tutarlıl1k veya bağlantı }\end{array}$ & 5.45 & 1.06 & 5.67 & .88 & -3.38 & $\mathrm{p}<0.001$ \\
\hline 4. Müzede kullanılan teknoloji & 4.56 & 1.34 & 4.90 & 1.25 & -4.11 & $\mathrm{p}<0.001$ \\
\hline 5. Müzenin içinde görsel animasyon & 4.13 & 1.60 & 4.23 & 1.39 & -1.03 & 0.302 \\
\hline 6. Müze dekorasyonu & 6.07 & 1.02 & 6.33 & .89 & -4.29 & $\mathrm{p}<0.001$ \\
\hline 7. Nesneler, koleksiyonlar veya sergiler & 5.65 & 1.16 & 6.42 & .88 & -10.82 & $\mathrm{p}<0.001$ \\
\hline 8. Müzenin konumu veya yeri & 6.32 & .75 & 6.25 & .80 & 1.61 & 0.107 \\
\hline 9. Müzenin ziyaret süresi & 5.51 & 1.10 & 5.46 & 1.07 & 0.66 & 0.507 \\
\hline $\begin{array}{l}\text { 10. Müzenin dışındaki tabela veya } \\
\text { yönler }\end{array}$ & 5.48 & 1.09 & 5.59 & 1.03 & -1.68 & 0.093 \\
\hline 11. Müzenin resepsiyonu / girişi & 5.50 & 1.01 & 5.59 & .99 & -1.52 & 0.128 \\
\hline 12. Giriş ücreti & 4.42 & 1.38 & 4.50 & 1.31 & -0.94 & 0.348 \\
\hline $\begin{array}{l}\text { 13. Özel gruplar için } \\
\text { (çocuklar, yaşl1lar) }\end{array}$ & 4.77 & 1.34 & 4.84 & 1.29 & -0.92 & 0.356 \\
\hline 14. Müzenin dış mimarisi & 6.38 & .81 & 6.49 & .73 & -2.24 & 0.026 \\
\hline 15. Müzenin bakımı & 5.14 & 1.40 & 5.59 & 1.12 & -5.30 & $\mathrm{p}<0.001$ \\
\hline 16. Hediyelik eşya dükkanı & 4.91 & 1.28 & 5.50 & 1.05 & -7.52 & $\mathrm{p}<0.001$ \\
\hline Ölçek ortalaması & 5.32 & .65 & 5.53 & .60 & -5.38 & $\mathrm{p}<0.001$ \\
\hline
\end{tabular}

Tablo 1'e göre müze içindeki tabelaların bilişsel imaja katkıları açısından iki müzede anlamlı bir farklılık bulunmamaktadır. Yorumsal materyal bakımından Topkapı Sarayı Müzesi'nin göreceli olarak Ayasofya Müzesi'ne göre daha iyi olduğu söylenebilir (t:-3.29; s.d.: 274; 
$\mathrm{p}<0.001)$. Müze içindeki farklı salonlar ve sergiler arasındaki tutarlılık açısından Topkapı Sarayı Müzesi'nin göreceli olarak Ayasofya Müzesi'ne göre daha iyi olduğu belirlenmiştir (t:-4.29; s.d.: 274; $\mathrm{p}<0.001)$.

Müze içerisindeki teknoloji bakımından Topkapı Sarayı Müzesi'nin göreceli olarak Ayasofya Müzesi'ne göre daha iyi olduğunu söylemek mümkündür (t:-4.11; s.d.: 274; p<0.001). Müze içindeki görsel animasyonların bilişsel imaja katkıları açısından iki müzede anlamlı bir farklılık yoktur. Müze dekorasyonu bakımından Topkapı Sarayı Müzesi'nin göreceli olarak Ayasofya Müzesi'ne göre daha iyi olduğu söylenebilir (t:-3.29; s.d.: 274; p<0.001). Müze içerisinde bulunan nesneler, koleksiyonlar veya sergiler açısından Topkapı Sarayı Müzesi'nin göreceli olarak Ayasofya Müzesi’ne göre daha iyi olduğu söylenebilir (t:-10.82; s.d.: 274; $\mathrm{p}<0.001)$.

Müzelerin konumu ve ziyaret süresinin bilişsel imaja katkısı açısından iki müzede anlamlı bir farklılık yoktur. Benzer şekilde, müzenin dışındaki tabelaların ve müzelerin girişi ve müzelerde uygulanan özel gruplar için indirimlerin (çocuklar, yaşlılar) bilişsel imaja katkıları açısından iki müzede anlamlı bir farklılık bulunmamaktadır. Müzelerin dış mimarisi açısından Topkap1 Sarayı Müzesi'nin göreceli olarak Ayasofya Müzesi'ne göre daha iyi olduğu söylenebilir (t:-2.24; s.d.: 274; p:0.026). Müzelerin bakımı açısından Topkapı Sarayı Müzesi'nin göreceli olarak Ayasofya Müzesi'ne göre daha iyi olduğu belirlenmiştir (t:-5.30; s.d.: 274; p<0.001). Müzelerin hediyelik eşya dükkanı bakımından Topkapı Sarayı Müzesi’nin göreceli olarak Ayasofya Müzesi'ne göre daha iyi olduğu söylenebilir (t:-7.52; s.d.: $274 ; \mathrm{p}<0.001)$.

Bilişsel imaj bir bütün olarak ele alındığında; Topkapı Sarayı Müzesi’nin Ayasofya Müzesi'ne kıyasla daha olumlu bir imaja sahip olduğunu söylemek mümkündür (t:-5.38; $\mathrm{p}<0.001)$.

Tablo 1'e göre Ayasofya Müzesi'nin bilişsel müze imajına göre en iyi bulunan ilk unsur müzenin dış mimarisi (6.38) olmuştur. Yabancı turistlere göre "müzenin dış mimarisi”" bilişsel imaj açısından en olumlu özelliğidir. Daha sonra müzenin konumu (6.32) ve müze dekorasyonu (6.07) gelmektedir. Ayasofya Müzesi'nin bilişsel imajı açısından göreceli olarak en kötü özelliği müzenin içindeki görsel animasyon (4.13)'dur.

Topkapı Sarayı Müzesi'nin bilişsel müze imajı açısından göreceli olarak en iyi bulunan özelliği müzenin dış mimarisi (6.49) olmuştur. Daha sonra müzede bulunan nesneler, koleksiyonlar ve sergiler (6.42) ve müze dekorasyonu (6.33) gelmektedir. Topkap1 Saray1 Müzesi'nin bilişsel müze imajı açısından göreceli olarak en kötü niteliği ise müzenin içindeki görsel animasyon (4.23) olmuştur.

İki müzenin bilişsel müze imajı dikkate alındığında göreceli olarak en iyi nitelikleri müzelerin dış mimarisidir. Bununla birlikte, iki müzenin bilişsel müze imajı değerlendirildiğinde göreceli olarak en kötü olan özellikleri müzenin içindeki görsel animasyonun yetersiz oluşu/olmamasıdır. 
Tablo 2. Duygusal İmaj Unsurlarının Müzelere Göre Karşılaştırılması

\begin{tabular}{|l|c|c|c|c|c|c|}
\hline & \multicolumn{2}{|c|}{ Ayasofya; n:275 } & \multicolumn{2}{|c|}{ Topkapı; n:252 } & \multicolumn{2}{c|}{} \\
\hline Duygusal İmaj & Ort. & S.Sapma & Ort. & S.Sapma & t-değeri & p değeri \\
\hline 1. Hoş Olmayan-Hoş & 6.00 & .95 & 6.33 & .76 & -5.83 & $\mathrm{p}<0.001$ \\
\hline 2. Sıkıcı- Canlandırıcı & 5.65 & 1.09 & 6.01 & .78 & -5.43 & $\mathrm{p}<0.001$ \\
\hline 3. Boğucu- Heyecan Verici & 5.61 & 1.12 & 5.86 & .95 & -3.812 & $\mathrm{p}<0.001$ \\
\hline 4. Bunaltıc1-Rahatlatıcı & 5.10 & 1.14 & 5.37 & 1.03 & -3.91 & $\mathrm{p}<0.001$ \\
\hline 5. Hareketsiz-Hareketli & 4.90 & 1.23 & 5.33 & 1.06 & -5.73 & $\mathrm{p}<0.001$ \\
\hline 6. Sıradan- Şaşırtıcı & 5.61 & 1.14 & 6.06 & .95 & -6.43 & $\mathrm{p}<0.001$ \\
\hline 7. Hüsrana Uğramış-Avunmuş & 5.55 & 1.16 & 5.95 & .95 & -5.70 & $\mathrm{p}<0.001$ \\
\hline Ölçek Ortalamaları & 5.49 & .87 & 5.84 & .68 & -6.77 & $\mathrm{p}<0.001$ \\
\hline
\end{tabular}

Tepki kategorileri: 1=Çok Güçlü, 2=Güçlü, 3=Biraz Güçlü, 4=Nötr, 5=Biraz Güçlü, 6=Güçlü, 7=Çok Güçlü

Tablo 2'ye göre duygusal imajın "hoş olmayan-hoş” özelliği bakımından Topkapı Sarayı Müzesi’nin göreceli olarak Ayasofya Müzesi'ne göre daha hoş olduğu söylenebilir (t:-5.83; s.d.: 274; p<0.001). İmajın “sıkıcı-canlandırıcı” özelliği açısından Topkapı Sarayı Müzesi’nin göreceli olarak Ayasofya Müzesi’ne göre daha canlandırıcı olduğunu söylemek mümkündür (t:-5.43; s.d.: 274; $\mathrm{p}<0.001)$.

Duygusal imajın "boğucu-heyecan verici” özelliği bakımından Topkapı Sarayı Müzesi'nin göreceli olarak Ayasofya Müzesi'ne göre daha heyecan verici olduğunu belirlenmiştir ( $\mathrm{t}: 3.81$; s.d.: 274; p<0.001). Duygusal imajın "bunaltıc1-rahatlatıcı" özelliği bakımından Topkap1 Sarayı Müzesi'nin göreceli olarak Ayasofya Müzesi'ne göre daha rahatlatıcı olduğu söylenebilir (t:-3.91; s.d.: 274; p<0.001).

İmajın "hareketsiz-hareketli" seçeneği bakımından Topkapı Sarayı Müzesi'nin göreceli olarak Ayasofya Müzesi'ne göre daha hareketli olduğu tespit edilmiştir (t:-5.73; s.d.: 274; $\mathrm{p}<0.001)$. Duygusal imajın "sıradan- şaşırtıcı" özelliği bakımından Topkapı Sarayı Müzesi'nin göreceli olarak Ayasofya Müzesi'ne göre daha şaşırtıcı olduğu belirlenmiştir (t:6.43; s.d.: 274; p<0.001). İmajın "hüsrana uğramış-avunmuş" özelliği açısından Topkapı Sarayı Müzesi'nin göreceli olarak Ayasofya Müzesi'ne göre daha avunmuş olduğu söylenebilir (t:-5.70; s.d.: 274; p<0.001).

Duygusal imaj bir bütün olarak ele alındığında; Topkapı Sarayı Müzesi’nin Ayasofya Müzesi'ne kıyasla daha olumlu bir imaja sahip olduğunu söylemek mümkündür (t:-6.77; $\mathrm{p}<0.001)$.

Tablo 2'ye göre Ayasofya Müzesi'nin duygusal müze imajı bakımından en iyi bulunan ilk unsuru "hoş olmayan-hoş" seçeneği $(6,0)$ olmuştur. Daha sonra sırasıyla "sıkıcı-canlandırıcı" 
seçeneği (5.65), “sıradan- şaşırtıcı” seçeneği (5.6182) gelmektedir. Diğer seçeneklere kıyasla en kötü unsur "hareketsiz-hareketli" seçeneği (4.90) olmuştur.

Topkapı Sarayı Müzesi'nin duygusal müze imajına göre en iyi bulunan ilk unsuru "hoş olmayan-hoş" seçeneği (6.16) olmuştur. Daha sonra "hüsrana uğramış-avunmuş" seçeneği (5.95), "boğucu-heyecan verici" seçeneği (5.86) gelmektedir. İki müzenin duygusal müze imajına göre en iyi bulunan ilk unsuru "hoş olmayan-hoş" seçeneği olmuştur. İki müzenin duygusal müze imajına göre en kötü bulunan unsuru "hareketsiz-hareketli" seçeneği olmuştur.

Tablo 3. Ayasofya Müzesi ve Topkapı Sarayı Müzesi’nin İmaj Ortalamalarının Karşılaştırılması

\begin{tabular}{|c|l|c|c|c|c|c|c|}
\hline \multirow{2}{*}{ Hipotez } & \multirow{2}{*}{ İmaj boyutları } & \multicolumn{2}{|c|}{ Ayasofya; n:252 } & \multicolumn{2}{|c|}{ Topkapı; n:275 } & \multirow{2}{*}{ t-değeri } & \multirow{2}{*}{ p-değeri } \\
\cline { 3 - 7 } & & Ort. & S.Sapma & Ort. & S.Sapma & & \\
\hline H1 & Bilişsel imaj & 5.32 & .65 & 5.53 & .60 & -5.38 & $\mathrm{p}<0.001$ \\
\hline H2 & Duygusal imaj & 5.49 & .87 & 5.84 & .68 & -6.77 & $\mathrm{p}<0.001$ \\
\hline
\end{tabular}

Araştırmanın ilk hipotezi, yabancı turistlerce algılanan bilişsel müze imajının Ayasofya ve Topkapı Sarayı Müzesi açısından farklı olduğu şeklindedir. Bu bağlamda, iki müzeye yönelik bilişsel imaj ortalamalarını tespit edebilmek için t-testi yapılmıştır. Tablo 3 'de de görüldüğü üzere iki müzenin bağımsız iki örnek t testi bilişsel müze imaj boyutuna göre yapılmıştır. Analiz sonuçlarına göre; Ayasofya Müzesi'ni ziyaret eden 275 yabancı turistin bilişsel imaj ortalaması 5.32 ve Topkapı Saray1 Müzesi'ni ziyaret eden 252 yabancı turistin ortalaması da 5.53'dir. Topkapı Sarayı Müzesi'ni ziyaret eden yabancı turistlerin bilişsel imaj ortalamasının Ayasofya Müzesi ziyaret eden yabancı turistlerin bilişsel imaj ortalamasından büyük olduğu tespit edilmiştir. Dolayısıyla iki müze arasında, bilişsel imaj boyutu açısından anlamlı bir farkl111k olduğu (t:-5.38; s.d.: 527; p<0.001) belirlenerek birinci hipotez kabul edilmiştir

Araştırmanın ikinci hipotezi, yabancı turistlerce algılanan duygusal müze imajının Ayasofya ve Topkapı Sarayı Müzesi açısından farklı olduğudur. Belirlenen iki müzeye yönelik duygusal imaj ortalamalarını tespit edebilmek için t-testinden yararlanılmıştır. Tablo 3'de de görüldüğü üzere araştırmada yer alan 2 müzenin bağımsız iki örnek $t$ testi duygusal imaj boyutuna göre yapılmıştır. Yapılan analizde; Topkapı Sarayı Müzesi'ni ziyaret eden 252 yabancı turistin duygusal imaj ortalamasının 5.84, Ayasofya Müzesi'ni ziyaret eden 275 yabancı turistin duygusal imaj ortalamasının ise 5.49 olduğu belirlenmiştir. Dolayısıyla duygusal imaj boyutu açısından iki müze arasında anlamlı bir farklılık olduğu (t:-6.77; s.d.: 527; p<0.001) belirlenerek ikinci hipotez kabul edilmiştir. Böylece, Topkap1 Saray1 Müzesi'ni ziyaret eden yabancı turistlerin duygusal müze algılarının Ayasofya Müzesi'ni ziyaret eden yabancı turistlerden daha yüksek olduğu ifade edilebilir.

\section{SONUÇ VE ÖNERILER}

Çalışmada; bilişsel ve duygusal müze imajı kavramları incelenmiş ve yabancı turistlerin iki müzeye yönelik bilişsel ve duygusal müze imaj algıları karşılaştırmalı olarak ortaya konmuştur. 
Duygusal imaj ile ilgili çıkarımlar: Topkapı Sarayı Müzesi'nin duygusal müze imajının (5.84) Ayasofya Müzesi duygusal imajından (5.49) yüksek olduğu tespit edilmiştir. İki müze ziyaretçilerinin duygusal müze imajı algısı arasında çok az bir fark vardır. Ancak analiz sonucunda elde edilen bulgularda duygusal imaj boyutu açısından anlamlı bir farklılık olduğu belirlenmiştir. Bu durumda; iki müzeyi ziyaret eden yabancı turistlerin müzelerin duygusal imaj algılarının farklı olduğu kanısı elde edilmiştir. Kırca (2008) çalışmasında katılımcılar tarafından en beğenilen müzenin Ayasofya Müzesi olduğunu ve Topkapı Sarayı Müzesi'nin ise ikinci olmuştur. $\mathrm{Bu}$ çalışmada iki müzenin de duygusal açıdan olumlu olduğu ancak birbirinden farklı olduğu söylenebilir. Dolayısıyla araştırmada ulaşılan sonuçların literatürle tutarlı olduğu anlaşılmaktadır.

Yabancı turistler iki müzenin duygusal müze imaj ortalamalarını "biraz iyi" olarak değerlendirmişlerdir. Bu durum, yabancı turistlerin iki müzeyi de duygusal imaj açısından olumlu bulduklarını ancak bunun sınırlı olduğunu göstermektedir. Ayrıca iki müzenin de duygusal imaj açısından eksikleri bulunmaktadır. Ayasofya ve Topkapı Sarayı Müzesi duygusal müze imajını etkileyen en önemli husus genellikle müzelerin hoş olmasıdır. Bu unsur yabancı turistlerce iyi olarak değerlendirilmiştir. Ayrıca yabancı turistler bu müzeleri canlandırıcı, şaşırtıcı, heyecan verici, avunmuş ve rahatlatıcı bulmaktadırlar. Ancak bu unsurlar genellikle yabancı turistler tarafından biraz iyi olarak değerlendirilmiştir. Her iki müze duygusal müze imajına göre hareketlilik unsuru bakımından düşük olarak değerlendirilmiştir. Bu unsurda genelde yabancı turistler kararsız kalmıştır. Duygusal imajın genel olarak unsurları ele alındığında Topkapı Sarayı Müzesi’nin Ayasofya Müzesi'ne göre daha iyi olduğu tespit edilmiştir.

Bilişsel imaj algısı ile ilgili çıkarımlar: Ziyaretçilere göre Topkapı Sarayı bilişsel müze imajı algısı $(5,53)$ Ayasofya Müzesi bilişsel müze imajı algısına (5.32) göre daha yüksektir. İki müze ziyaretçilerinin bilişsel müze imajı algısı arasında çok az bir fark vardır. Ancak analiz sonucunda elde edilen bulgularda bilişsel imaj boyutu açısından anlamlı bir farklılık olduğu belirlenmiştir. Bu durumda; iki müzeyi ziyaret eden yabancı turistlerin müzelerin bilişsel imaj algılarının farklı olduğu sonucuna ulaşılmıştır. Alan yazında Demir (1998) tarafından Ayasofya Müzesi'nin çeşitli özelliklerinin (park yeri, yön gösterme, koleksiyon, müze bakımı) yerli turistler tarafından değerlendirildiği çalışmasında; turistlerin genellikle fikir belirtmediği, fakat fikir belirten turistlerin ise Ayasofya Müzesi'nin özelliklerini olumlu bulduğu tespit edilmiştir. Özgören (2007) çalışmasında yerli turistlerin, Topkap1 Sarayı Müzesi'nin özelliklerini (müze binası, çalışma saatleri, koleksiyonlar, yön gösterme tabelaları, giriş ve çıkış bölümleri, müze bakımı) genel olarak iyi olarak belirtmiştir. Bu iki çalışmada, elde edilen bilişsel imaj öğelerinin benzerlik gösterdiği ancak, bilişsel imaj açısından iki müzenin de farklı olduğu anlaşılmaktadır. Bu bağlamda bu araştırmanın ilk hipotezi mevcut alan yazın ile benzerlik göstermektedir.

Yabancı turistlerin bilişsel imaj algıları ile ilgili; elde edilen bulgularda yabancı turistler iki müzenin bilişsel müze imaj ortalamalarını "biraz iyi" olarak belirtmişlerdir. Buna göre; yabancı turistlerin iki müze ile ilgili bilişsel imaj ortalamaları dikkate alındığında "iyi”" veya "çok iyi" olarak değerlendirmedikleri görülmektedir. Yabancı turistler iki müzenin de bilişsel imajını olumlu olarak değerlendirmekte ancak "biraz" ifadesi dikkate alındığında olumlu görüşün sınırlı olduğu görülmektedir. Ayrıca iki müzenin de bilişsel imaj açısından eksikleri mevcuttur. 
Ayasofya ve Topkapı Sarayı Müzesi’ne bilişsel müze imajına genellikle müzelerin dış mimarisi, konumu, müze dekorasyonu, müze içerisindeki nesneler, koleksiyonlar ve müze içerisindeki tabelalar katkıda bulunmuştur. $\mathrm{Bu}$ unsurlar genellikle yabancı turistlerce iyi olarak değerlendirilmiştir. İki müzenin bilişsel müze imajına göre göreceli olarak müzenin içindeki görsel animasyonlar, müzenin giriş ücreti, müzelerde yer alan teknoloji, özel gruplar için indirimler ve müzelerin hediyelik eşya dükkânları en kötü unsurlardır. Bu unsurlar da genelde yabancı turistlerce normal olarak değerlendirilmiştir. Bilişsel imajın genel olarak unsurları ele alındığında Topkapı Sarayı Müzesi, Ayasofya Müzesi’ne göre daha iyi durumdadir.

Çalışma; alan yazına yabancı turistlerin Ayasofya ve Topkapı Sarayı Müzesi'ne yönelik bilişsel ve duygusal müze imajı algısını incelemesi açısından katkıda bulunmaktadır. Türkiye'de, alan yazında yabancı turistlerin bilişsel ve duygusal müze imajı algısını belirlemeyi amaçlayan herhangi bir araştırmanın bulunmadığı görülmektedir. Araştırma bu bakımdan bir ilktir. Bu nedenle araştırma alan yazındaki boşluğun doldurulmasına katkıda bulunmakta ve müze imajının ve boyutlarının önemine vurgu yapmaktır.

Yabancı turistlerin bilişsel ve duygusal müze imajının algılarının belirlenmesi, müzelerle ilgili memnuniyetlerinin ve eleştirilerinin ortaya konması ve değerlendirilmesi, müzelerin geliştirilmesine, yetkililerin doğru pazarlama kararları alabilmelerine katkıda bulunabilir. Kültür Varlıkları Müze Genel Müdürlüğü, Kültür ve Turizm Bakanlığı, seyahat acenteleri, bu çalışmadan elde edilen sonuçlardan müzelerin geliştirilmesi için yararlanabilirler. Böylece bu çalışma müzelerin bilişsel ve duygusal imajının geliştirilmesi açısından yetkililere yol gösterici olabilir.

Çalışma Ayasofya ve Topkapı Sarayı müzelerinin bilişsel ve duygusal imajlarının birbirinden farklı olduğunu; Topkapı Sarayı Müzesi'ne yönelik bilişsel ve duygusal müze imaj algısının Ayasofya Müzesi'ne göre daha olumlu olduğu sonucuna ulaşılmıştır. Ancak iki müzede ziyaretçiler tarafindan "çok iyi" olarak değerlendirilmemiştir. Bu sebeple iki müzenin dünyadaki diğer müzelerle rekabet edebilmesi ve ziyaretçiler tarafından "çok iyi" olarak değerlendirilebilmesi için; Kültür ve Turizm Bakanlığı ve Kültür Varlıkları Müze Genel Müdürlüğü'nün iki müze ile ilgili eksikleri saptayıp iyileştirme yönünde çalışmalar yapması gerekmektedir.

Çalışma kapsamında ilgili kurumlara müzelerde yapılması gereken düzenlemeler açısından şu öneriler sunulmaktadır:

- Teknoloji ve görsel animasyon seviyesinin artırılması,

- Yorumsal materyallerin bilgi kısımlarının artırılması ve farklı dillerde sunulması,

- Müzede yapılan sergi ve koleksiyonların çeşitlerinin ve sayısının artırılması,

- Müze içerisindeki salonlar arasındaki geçişlerin uygun olması,

- Müzenin içinde ve dışında bulunan yön gösterici tabelaların turistlerin bulunduğu gezdiği merkezi ulaşım noktalarına yerleştirilmesi, sayısında artış sağlanması ve farklı dillerde olması,

- Ziyaret süresinin artırılması ve yaz-kış sezonları göz önüne alınarak müzelerin erken saatlerde açılması, 
- Müzelerin restorasyonu ve mimarisinde düzenlemeler yapılması,

- Hediyelik eşya dükkanındaki fiyatların daha uygun olması ve çeşitlerin artırılması.

Kurumlar tarafından gerçekleştirilecek düzenlemeler ile bilişsel unsurların geliştirilmesi, aynı zamanda ziyaretçilerin duygusal imaj algılarının da (hoş, bunaltıcı, rahatlatıcı, heyecan verici gibi) olumlu yönde değişmesine neden olabilecektir. Ziyaretçilerin beklentilerine uygun ve onları memnun edecek bir hizmetle karşılaşma oranları artacaktır. Bu noktada, seyahat acentaları, müzelerde eksiklerin giderilmesi ile birlikte, ziyaretçilerin memnuniyetlerinin artmasına bağlı olarak pazarlama faaliyetlerinde daha etkin olabilirler. Müze ziyaretlerinden memnun kalan kişiler, seyahat acentasından aldıkları hizmeti de olumlu olarak değerlendireceklerdir. Dolayısıyla, seyahat acentalarının tercih edilmesi ve turlara yönelik talep artışının olması kaçınılmaz olacaktır.

\section{ARASTTIRMANIN KISITLILIKLARI}

$\mathrm{Bu}$ çalışmada her araştırma gibi ölçeğin yapısal özelliklerinden dolayı kısıtlamalar vardır. Çalışma Ayasofya ve Topkapı Sarayı Müzesi'ni 8 Aralık 2018-8 Şubat 2019 tarihleri arasında ziyaret eden yabancı turistler ile sınırlıdır. Araştırmaya Türkiye'de bulunan bu iki müze dışındaki diğer müzeleri ziyaret eden yabancı turistler dâhil edilmemiştir. Araştırma sonuçları bu iki müzeden elde edilen verilerle sinırlıdır.

$\mathrm{Bu}$ nedenle araştırma sonuçları Türkiye'de bulunan diğer müzeler için genellenemez. Çalışmada, yabancı turistlerin ana kütlesine ulaşılmasının neredeyse imkânsız olması ve müzeleri gezen yabancı turist sayısının 10.000 'den fazla olması nedeniyle sınırsız evrenlerde ortalama için kullanılan örnek büyüklüğü hesaplama formülü kullanılmıştır. Bu durumda bir kisitlamayı meydana getirmektedir.

\section{KAYNAKÇA}

AKBULUT, B. A. (2014). Turistik Destinasyon Olarak Ankara'nın Bilişsel ve Duygusal İmaj Bileşenleri Açısından Analizi, Yüksek Lisans Tezi. Gazi Üniversitesi, Eğitim Bilimleri Enstitüsü, Ankara.https://tez.yok.gov.tr/UlusalTezMerkezi (Tez No. 366350).

AKSOY, E. (2016). İstanbul'daki Devlet Müzeleri ve Özel Müzelerin Reklam Stratejileri Açısından Değerlendirilmesi, Yüksek Lisans Tezi. İstanbul Kültür Üniversitesi, Sosyal Bilimler Enstitüsü, İstanbul. https://tez.yok.gov.tr/UlusalTezMerkezi (Tez No. 436974).

ALPAR, R. (2016). Spor, Sağlık ve Eğitim Bilimlerinden Örneklerle Uygulamalı İstatistik ve Geçerlik-Güvenirlik, Detay Yayıncılık, Ankara.

ALTINBAŞAK, İ. ve YALÇIN, E. (2009). “City Image and Museums: The case of İstanbul”. International Journal of Culture, 4(3): 241-251.

Ayasofya Müzesi , “Ayasofya Müzesi Tarihçe”, ayasofyamuzesi.gov.tr/tr/content/tarihçe, 21.04.2019.

BALOĞLU, Ş. ve MCLEARY ,K.W. (1999). “A Model of Destination İmage Formation”. Annals of Tourism Research, 26(4): 868-897.

BEERLİ, A. ve JOSEFA, D. M. (2004). "Factors Influencing Destination Image". Annals of Tourism Research, 31(3): 657-681. 
BOYAR, H. (2006). Bilgi Toplumu Oluşumu ve Küreselleşmenin Kentsel Mekana Etkilerinde Müzeler Örneği. Yüksek Lisans Tezi, Gazi Üniversitesi Fen Bilimleri Enstitüsü, Ankara.https://tez.yok.gov.tr/UlusalTezMerkezi (Tez No. 180371).

ÇERÇİ, A. (2013). Destinasyon Markalama ve Yavaş Şehir Seferihisar'ın Destinasyon Marka İmaj1, Yüksek Lisans Tezi. Hacettepe Üniversitesi, Sosyal Bilimler Enstitüsü, Ankara. https://tez.yok.gov.tr/UlusalTezMerkezi (Tez No. 339056).

DEMİR, C. (1998). Müzelerde Pazarlama: Müze-Ziyaretçi İlişkilerinde Çağdaş Pazarlama Yaklaşımı, Yüksek Lisans Tezi. Anadolu Üniversitesi, Sosyal Bilimler Enstitüsü, Eskişehir. https://tez.yok.gov.tr/UlusalTezMerkezi (Tez No.73419).

GIL, S. M. ve RITCHİE, J.R. (2009). "Understanding the Museum Image Formation Process". Journal of Travel Research, 47(3): 480-493.

GIL, S. M. ve RİTCHİE, J.R. (2017)."Research Based Guidelines for Effective Visitation Management of Museums Image”. International Journal of Culture, 11(4): 534-550.

GÜRKAN, Z. (2008).Konaklama İşletmelerinde Kurumsal İmajın Tüketici Tercihlerine Etkileri Üzerine Bir Araştırma, Yüksek Lisans Tezi. Sakarya Üniversitesi, Sosyal Bilimler Enstitüsü, Sakarya. https://tez.yok.gov.tr/UlusalTezMerkezi (Tez No. 228618).

HATCH, M. J. ve SCHULTS, M. (1997). "Relations between Organizational Culture, Identity and Image". European Journal of Marketing, 5(6): 356-365.

ICOM, Milletlerarası Müzeler "Müze Tanımı", http://www.kulturvarliklari.gov.tr/TR,44442/icom.html, 26.08.2018.

İstanbul İl Kültür ve Turizm Müdürlüğü (2018). “İstanbul İstatistik Raporları”, http://www.istanbulkulturturizm.gov.tr/Eklenti/62367,aralik-2018pdf.pdf?0,

22.05.2019.

KERVANKIRAN, İ. (2014). “Dünya'da Değişen Müze Algısı Ekseninde Türkiye'deki Müze Turizmine Bakış”. International Periodical For The Languages, Literature and History of Turkish or Turkic, 9(11): 345-369.

KIRCA, S.S. (2008). Tüketicilerin Müze Ziyaret Alışkanlıkları ve Müze Tercihlerini Etkileyen Faktörler Üzerine Bir Araştırma, Yüksek Lisans Tezi. Sakarya Üniversitesi, Sosyal Bilimler Enstitüsü, Sakarya. https://tez.yok.gov.tr/UlusalTezMerkezi (Tez No. 228834).

KOTLER, N. ve KOTLER, F. (2000). "Can Museums be All Things to All People?: Missions, Goals, and Marketing's Role”. Museum Management and Curatorship, 18(3): 271-287.

KTB, Kültür ve Turizm Bakanlığı (2019). "Müze Tanımı", http://pdb.kulturturizm.gov.tr/TR,137113/muze-nedir.html, 26.06.2018.

MERCIN, L. (2003). "Kültür ve Sanat Değerlerinin Yaşatılmasında Müzelerin Rolü”. Elektronik Sosyal Bilimler Dergisi, 2(6): 106-114. 
ÖZGÖREN, F. (20017). Boş Zaman Pazarlaması ve Müzecilikte Bir Uygulama, Yüksek Lisans Tezi. Marmara Üniversitesi, Sosyal Bilimler Enstitüsü, İstanbul. https://tez.yok.gov.tr/UlusalTezMerkezi (Tez No. 209943).

TDK, Türk Dil Kurumu, “TDK İmaj Tanımı”, sozluk.gov.tr, 19.03.2019.

Topkapı Sarayı Müzesi, “Topkapı Sarayı Müzesi Tarihçe”, topkapisarayi.gov.tr/tr/tarihçe, 21.04.2019.

URAL, A. ve KILIÇ, İ. (2013). Bilimsel Araştırma Süreci ve Spss ile Veri Analizi, Detay Yayincllık, Ankara.

VAUGHAN, R. (2001). "Images of a Museum". Museum Management and Curatorship, 19(3): 253-268.

YAZICIOĞLU, İ. Ve AKBULUT, B.A. (2015). "Turistik Destinasyon Olarak Ankara'nın Bilişsel ve Duygusal İmaj Bileşenleri Açısından Analizi”. Journal of Tourism and Gastronomy Studies, 3(3): 136-144.

YOLAL, M. (2016). Turizm Araştırmalarında Örnekleme - Bibliyometrik Bir Araştırma, Detay Yayıncılık, Ankara. 